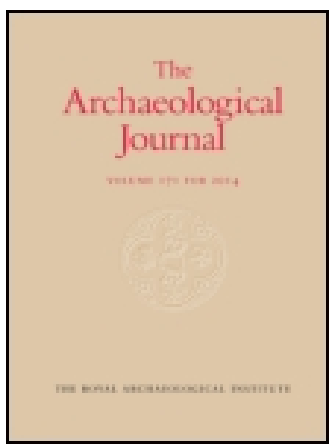

Archaeological Journal

\title{
Original DocumentsWinchester in the Thirteenth Century
}

\section{E. Smirke}

To cite this article: E. Smirke (1850) Original DocumentsWinchester in the Thirteenth Century, Archaeological Journal, 7:1, 374-383, DOI: $\underline{10.1080 / 00665983.1850 .10850795}$

To link to this article: http://dx.doi.org/10.1080/00665983.1850.10850795

Published online: 06 Dec 2014.

Submit your article to this journal $\sqsubset$

Q View related articles $\square$

Citing articles: 1 View citing articles 4 


\section{Grínínal 国ocuments.}

\section{WINCHESTER IN THE THIRTEENTH CENTURY.}

The following Inquest, which Mr. Hunter kindly brought under my notice some years ago, was found among the Miscellaneous Exchequer Records of the Queen's Remembrancer's Office. The contents may be of some value to a future historian of the city of Winchester.

\section{VEREDICTUM XII JURATORCM WINTON.}

Dicunt quod tempore Henrici regis, patris domini Edwardi qui nune est, Willielmus de Ralige tunc Wintoñ episcopus appropriavit sibi medietatem vici extra portam borialem Winton et medietatem vici extra portam occidentalem Winton, qua solebant esse in manibus ejusdem $H$. regis et predecessorum suorum et pertinentes civitati suæ prædictse, et per quos. (quod? ) tenentes medietatem dictorum vicorum a tempore illo subtraxerunt et seperarunt $a b$ omnibus honeribus dictum regem et civitatem prædictam contingentibus ; unde per illam appropriationem magna utensilia in quibus Qperantur burelli et chalones in magna parte in illam libertatem sic appropriatam se subtrahunt: Et quod quodlibet tale utensile debet domino regi quinque solidos per annum in illa libertate infra quinque leucas circa Winton: Et similiter quodlibet utensile in quibus operantur duplici chalones xii denarios per annum; et in quibus operantur singuli chalones vi den. per ann. : Et quia in illa libertate sic appropriatâ nichil solvunt, eo quod ballivi Winton non habent ingressum in illam libertatem ad districtiones faciendas sicut prius facere consueverunt, ferè omnes operarii burellorum et chalonum a civitate se subtrahunt et ibi manent, et omnes alii tenentes domini episcopi adeo liberi sunt sicut alii de gilda mercatoriâ ad emendum et vendendum omnimodas mercandisas ad magnum damnum civitatis prædictæ.

Item cum coronatores civitatis Winton venirant ab (ad?) abbatiam de Hyda, et vellent videre quendum mortuum, scilicet bernarium ${ }^{1}$ domini regis, et suum facere officium, prædictus abbas et sui non permiserunt; set dominum W. de Suttone, coronatorem totius comitatus, fecerunt venire per quandam posternam, quæ seducit ad Bertonam quæ est in luundredo de Mucheledevere, ad predictum officium faciendum, in præjudicium libertatis prædictæ.

Item Abbas de Hyda appropriavit sibi totam abbatiam et curiam suam quæ pertinens est civitati in precinctu libertatis ejusdem ad appropriandum (appruandum?) hundred' sua (suum?) de Mucheledevere; ita quod coronatores nec ballivi civitatis prædictæ possunt facere suum officium de felonibus et malefactoribus sicut solent et debent. Et quamplures tenentes domini regis sectam domino regi debentes et alia honera et servitia facientes. ${ }^{2}$

1 Bernarius here means one of the king's dog-feeders. See Hearne's Liber Niger, vol. i., p. 357. Ducange voc. Brennarii. Ejusd. Gloss. Franc. voc. Bernier. So called from the bran used for that purpose. Hearne, who is rarely happy in etymological conjectures, supposes him to be the king's bear-ward.
2 The sentence beginning " Et quamplures," \&c., is either part of the preceding sentence, and ought not to be separated from it, or is an imperfect sentence without any verb. The following word, here written "Dictus," is open to doubt in the original MS. 
Dictus abbas loca et tenementa illa sibi appropriavit et prædicta penes se inclusit per murum, ad damnum et detrimentum, etc.

Item dicunt quod quædam magna domus in Winton quæ vocatur vetus monetrium, ubi nunc stat draperia civitatis ejusdem, fuit aliquando in manibus antecessorum domini regis. Et cum Normannia deforceretur domino regi Johan, quidam Walterus de Pavely, tunc Major civitatis Rotomagensis, fideliter adherens prædicto domino regi ut ligio domino suo, fuit totaliter destructus et a rengno regis Franciæ exulatus: per quod prædictus dominus rex Johannes contulit eandem domum prædicto Waltero pro damnis et jacturis quas pro ipso sustinuit. Idem vero Walterus obiit absque hærede de corpore suo, per quod dicta domus per mortem ejusdem Walteri futi escæta iterum domini regis, et sic stetit per multum tempus vacua et fere ruinosa usque ad mortem domini regis prædicti. Unde dominus H, rex fecit eam extendere ad certum valorem per sacramentum legalium virorum; et fuit extensa ad sex libras et tradita civibus Winton. pro prædicto redditu. Postea cum firma civitatis deteriaretur (sic) per appropriationem predicti suburbii, per quod cives ejusdem civitatis noluerunt nec potuerunt eandem firmam tenere, idem dominus $H$. rex assignavit prædictas sex libras eidem firmæ una cum aliis redditibus, terragiis, et aliis rebus qua habuit in manu sua in civitate eadem. Processu vero temporis quidam Nicholaus Koppinger, tunc Major Winton, nitebatur expellere tenentes dictæ domus et removere draperiam in alium locum, promisit domino regi $\mathrm{lx}$ solidos per ann. ultra prædictas vi libras. Et cum dominus rex videret quod non posset (sic) tenentes expellere absque injuria ${ }^{3}$ eisdem facienda, non concessit prædicto Nicholao quod postulavit. Tamen prædicti sexaginta solidi per eundem Nicholaum sic promissi solvuntur ad scaccariam domini regis quolibet anno per manus ballivorum Wintón; unde dicta domus reddit per annum ix ${ }^{\text {li }}$; scil. vi li firmæ civitatis, et $1 x^{\text {sol }}$ ad scaccariam prædictam.

Item dicunt quod magna domus, quam Rogerus Dalerun modo tenet, solebat esse in manibus antecessorum domini regis, et tradita fuit eodem tempore cuidam Ricardo Brian pro L solidis quos vicecomes Suth'ton qui pro tempore fuerit modo recipit, set nesciunt si habeat warentum, etc.

Item dicunt quod quædam magna domus cum pertinentiis, in qua venduntur panni linei in Winton, solebat esse in manibus antecessorum domini regis, donec dominus rex Johannes eandem domum cum libertatibus, consuetudinibus, et aliis pertinentiis suis dedit Willielmo cissori suo pro servitio suo reddendo inde domino regi et hæredibus suis unum peliceum de griso per annum. Postea vero Willielmus filius dicti Willielmi feofavit de dicta domo Hugonem de Stoke. Et hæredes Hugonis de Stoke feofaverunt Will. de Dunstaple,qui nunc tenet.

Item dicunt quod quædam terra extra portam occidentalem Winton quæ vocatur le Muves, in qua sita est quædam domus et quoddam columbare, $q^{4} æ^{4}$ solebat esse in manibus antecessorum domini regis ; et quod dominus rex Johannes, qui frequenter et multum morabatur in castro Wintoń, eandem terram sibi comparavit et domum ibidem construxit ad mutandum aucipites (sic) suos, et eam tenuit et inde seisitus obiit. Et dominus Henricus rex fuit etiam seisitus, quousque eandem terram tradidit cum pertinentiis suis de sua mera voluntate Reginaldo filio Petri qui eam nunc tenet, set utrum inde habeat warentum, vel non, ignorant.

Item de tall[iis] contra diversos vic' unam proponunt contra Philippum

VOL, VII.

4 The our seems superfluous.

3 “ Injuriam" in orig. $3 \mathrm{D}$ 
de Homile continentem xl sol.o (The jury also find nine other tallies of various debtors, amongst them are tres tallias de auro Reg', $x$ xi $^{l i}$ xiii sol.)

Item de redditibus pertinentibus ad firmam Winton: Dicunt de draperia per ann. ${ }^{1}{ }^{1 i}$. De redditibus fullonum ${ }^{l i}$. De redditu assiso de Laugablo:-

\section{Extra portam occident.}

[Here follows a long list of names of persons pajing for Langable various sums from $1 d$. to $2 s .8 d$. for their respective tenements.]

Summa, xix ${ }^{\text {s }}$ ijj $^{d}$

Galpestret. [Names and sums follow.]

Summa, $x i^{s} \nabla^{d}$

Snythelingestret. [Names, \& $\varepsilon^{\mathrm{c}}$, follow.]

Summa, ii ${ }^{5}$ iiij $^{d}$

Brudenestret. [Names, \& $\&^{c}$.]

Summa, ix ${ }^{s}$ iiij ${ }^{d}$

Shortenestret. [Names, \&c.]

Summa, viij $\mathbf{s} \mathbf{v}^{\mathbf{d}}$

Alwarestret. [Names, \&c.]

Summa, $v^{s}$ ij $^{d}$

Munstrestret. [Names, \& $\mathbb{E}^{\mathrm{c}}$.]

Summa, $x i^{\text {s }}$ vij ${ }^{d}$

Shuldwortestret. [Names, \&c. ]

Summa, iv id $^{\mathrm{d}}$

Wonegerestret. [Names, $\&^{c}$.]

Summa, ii s ${ }^{\text {id }}{ }^{d}$

Tannerestret. [Names, \& $\&^{c}$.]

Summa, $\mathrm{vij}^{\mathrm{s}} \mathrm{vi}^{\mathrm{d}}$

Buckestret. [Names, \&c.]

Summa, xvi d

Garestret. [Names, \& $\mathrm{c}^{\mathrm{c}}$.]

Summa, ix $x^{a}$ ob.

Goldstret. $\quad$ [Names, $\&^{c}$.]

Summa, viij s ii $^{d}$

Memorandum quod domus, ubi Cokerellus Judeus mansit, debet de langabulo per ann. $\mathrm{ij}^{\mathrm{s}}$, qui per multum tempus per ballivos Wintoń non fuerunt levati.

In Mangno vico.

[The names under this head are numerous; among others are the following:]

De monachis Sancti Barnabæ, xviij d

De terra monachorum Saneti Swithini. iij ${ }^{\text {s }}$

De abbatia Sanctæ Mariæ, $x^{d}$

De novem terris vacuis retro draperiam, iiii $^{{ }^{3}} \mathrm{vi}^{\mathrm{d}}$

Summa, $x x^{3} x^{8}$ ij $^{\text {d }}$

Item de consuetudinibus villæ prædictæ ; -

De consuetud' burellorum et chalonum per ann., $\mathrm{lx}^{\mathrm{s}}$

De consuetud' portarum a festo $\mathrm{S}$. Michis usque festum S. Egidii cum feriis $\mathbf{S}$. Barnabæ et S. Swithini, iiij is

De consuetud' pesagii per idem tempus, $\mathrm{xl}^{\mathrm{s}}$

5 Vic' is the usual abbreviation of vicecomes and its cases. 
De consuetud' piscium per idem tempus, iiii li

De consuetudinariis et minutis consuetudinibus per prædictum tempus, $\mathrm{lx}^{\mathrm{s}}$

De placitis et pirquisitis per idem tempus, $\mathrm{c}^{\mathbf{s}}$ Summa, xxili

Item ab In crastino exaltationis $\mathbf{S}$. Crucis usque festum S. Michis ut in pesagio lanæ et consuetudine intrantium et exeuntium, et placitis et perquisitis, et de consuetudine portarum, et aliis permissionibus mercatorum, et escaetis, 1. marc. Summa, 1. marc.

Et sciendum est quod antequam $P$. de Rupibus appropriavit sibi suburbium Winton, omnes et singuli suburbanii, qui operabantur burellos, solebant reddere pro utensili suo v. solidos per ann. Et quilibet operator chalonum in quo operabantur magni chalones, xii. den. Et quilibet operantes parvos cbalones, vi. den.

Summa summarum, Ixxviij li iiii $^{\text {s }} \mathrm{x}^{\mathrm{d}}$

Nomina, xii. juratorum:

Will. le Specir.

Adam Povere.

Ric. de Stogbridge.

Job. Russel.

Joh. Moraunt.

Joh. le Cras.

Hugo de Fulfloud.

Andr'. Beaublet.

Will. Strut.

Will. de Ocely.

Walt. de Kaperigge.

Tho. le Paumer.

Assuming the finding of the jury to be true, we obtain from it some curious information.

It charges William de Raley, or Ralige (bishop of Winchester between the years 1243 and 1249), with having appropriated parts of the suburb near the north and west gates of the City of Winchester, formerly in the hands of the crown and parcel of the city. The latter part of the record attributes this encroachment to the preceding bishop, Peter de Rupibus. Perhaps the usurpation continued under both prelates. The alleged appropriation is of the moiety of a "vicus" without each of the two gates. In documents of this sort, and at this date, vicus usually means what we now call a street; and this must be its import here, as it certainly is in the subsequent list of streets. The bishop, no doubt, claimed them as part of the Soke Liberty; all the lands of the See within or immediately circumjacent about the walls having immemorially composed the manor and franchise of that name.

It states that every " utensile," or loom, within the liberty, and within the circuit of five leagues round, in which clothes, called burrells, were woven, paid 5s. per an. to the king; and that every weaver of double chalons, paid Is. per an., and of single chalons, $6 \mathrm{~d}$. per an.

That by including these suburban districts within the episcopal liberty the weavers were withdrawn from the jurisdiction of the city bailiffs, and thereby escaped the above payments and other charges due to the king and the city; and that they had accordingly left the city, and settled in the more favoured suburbs. The clialones seem to have been blankets or coverlets (Prompt. Parvulorum, ad voc., and the note of $\mathrm{Mr}$. Way, ibid.), whence the surname of Chaloner. The burillers were a branch of the 
woollen cloth-workers or weavers, well known in the early history of the London companies. (Herbert, vol. i. p. $25-27$; vol. ii. p. 645.)

That the Abbot of Hyde claimed to include the whole suburban precinct of the abbey within his hundred of Mitcheldever, and thereby to exclude the city coroner from exercising his office therein, and to exempt various tenants of the king from their suit and services of right due to the crown.

That the great drapery hall, called the Old Mint, had been formerly in the hands of the crown, and was granted by King John to Walter de Pavely, ex-mayor of Rouen, to indemnify him for the losses he had suffered by his faithful adherence to the King of England and consequent expulsion from Normandy. That after the death of Walter it remained vacant for many years, till it was demised to the citizens by King Henry III. at the appraised value of six pounds per annum. That on the depreciation of the city rents, by reason of the above encroachments on the suburbs, the same king assigned the $6 l$. and other rents to the farm of the city,-that is, allowed the amount in their farm. That Nicholas Coppinger, mayor of Winchester, tried to expel the tenants and remove the Drapery, and promised to pay to the crown an additional rent of $3 l$. ; and that, although he failed in his object, the extra rent continued to be paid to the Exchequer, and that the whole annual rent of the house was therefore $9 l$.

That the rent of a large house, formerly demised by the crown to Richard Brian at $50 \mathrm{~s}$. rent, was now received by the Sheriff of Hampshire from the present tenant, Roger Dalerun.

That the large house, used, at the time of the Inquest for the sale of linen cloth, had been granted by King John to his tailor, William, by the service of rendering yearly to the King and his heirs one fur pelisse; and that the house had descended to his son, William, from whom it had passed by successive feofments to Hugh de Stoke and to William de Dunstaple, the present possessor.

That the land called the Mewes, on the west side of the city, in which were a house and dovecote, had been bought by King John for the mewing of his hawlss: That John lived often and long at the castle, and that Henry III. demised (tradidit) it (probably the house) of his mere will to Reginald, the son of Peter, who was the present holder; by what warrant the jury know not.

After enumerating certain tallies of debts, including arrears of the aurum reg[inœ] (on which Prynne has poured out so much learning), the Jury specify the annual rents payable in respect of the Drapery, already noticed, and the fullers, and then state in detail the persons and tenements charged with the rents of Assise, called langable, $i$. e., land-gavel, in all the principal streets of the city. The great majority were payable by tenants in the High Street and without the West Gate. Among them are the monks of St. Swithin, and of St. Barnabas, that is, Hyde Abbey ; and the nuns of St. Mary. All the streets here named occur in the two Inquests in the reign of Hen. I. and Stephen, which form the well known Liber Winton. A plate in the quarto edition of Milner's History, cbiefly copied from Godson's map, explains the situation and present names of most of them, and the variations in them are further traced down to a later date in the recent octavo, or 3rd, edition.

There are, therefore, at least, five distant and widely separated dates, at which we have authentic and accessible materials for the ancient topography of Winton, namely, a charter of Eadward, of Wessex, A. D. 901-909 (Cod. 
Dipl., vol. v. p. 163), which notices the four main streets of the city; the Inquest of Hen. I., describing the revenues, \&c. of the crown in the city in the time of Edward the Confessor, and incidentally containing information applicable to the date of the Inquest itself; the Inquest taken under the precept of Bishop Henry of Blois, in 1148; the Inquest now laid before the reader; and the well known petition of the citizens to the crown at the close of the reign of Hen. VI. ${ }^{6}$

The enumeration of streets and tenements in these surveys lends but little support to the statement of Dr. Milner, that in the reign of Henry 1. the suburb extended " a mile in every direction further than they do at present" (i.e. in 1798. See vol. i. p. 157, 3 ed.) I presume that the author meant a populous suburb of houses and buildings, such as we see at Bristol, London, and in other cities which have outgrown their walls. If this be true, then Winchester must have been, at least, twenty times as large and populous as it was in 1841 , when there were about 1800 houses and 10,700 inhabitants. ${ }^{7}$ This is improbable in itself, and is not easily reconcileable with the evidence. The surveys of Henry I. and of Edward I. do not supply trustworthy materials for calculation, because they purport to be only partial surveys for limited purposes; but that of Bishop de Blois in 1148 is more comprehensive, and evidently embraces all tenements yielding rent to any landlord either within or without the four gates. This, of course, excludes the sites of ecclesiastical and eleemosynary buildings, and of royal and episcopal castles or mansions. The date of the survey is only thirteen years after the close of the reign of Henry $\mathrm{I}$.

Now, allowing to every tenant paying rent a separate house (an improbable state of things), the survey of De Blois indicates, on a rough estimate, about 1200 tenements, occupied by a mixed population,-a number quite inadequate to form a town of the magnitude attributed to Winchester in the 12th century, even after making due allowance for the sieges and conflagrations which marked the reign of Stephen. ${ }^{8}$ If any populous suburb of the extent supposed had really existed, we should have found it divided into streets and lanes, as in the older and central parts; yet it is remarkable that we find no trace of any other streets in the early surveys than those which are known to exist at this day, and which are chiefly confined within the old walls. The great number of parochial and other churches has been relied upon as proof of the vast extent of the city in the 11 th and 12 th centuries (Ellis's Introd. to Domesday, vol.i. p. 190); and this evidence would be of some value if a church had then meant what it now means, viz., a place provided only when and where necessary for public worship. It is, however, certain that many of these were small and crowded within

6 Printed in Archæologia, vol i,, p. 91.

7 The old enceinte of the city is a parallelogram about half a mile in length, and three furlongs and a half in breadth. The suburban streets adjacent (exclusive of those built since the completion of the railway) were, it is believed, taken as part of the city in the census of 1841. They at that time formed no very important addition to the number either of houses or population.

8 The effect of conflagrations appear to be much magnified by our early chroniclers. The authorities state that Winchester was burnt down in A:D. 1102. Yet in the same reign, a few years afterwards, " Winchester attained the zenith of its prosperity," and was replete with "magnificent buildings," castles, palaces, guildhalls, and an " incredible number of parish churches and chapels" (vide Milner, vol. i., p. 152, 156,157 , ed. 3). Instances of exaggeration of this sort are very frequent in the old annalists. "Ecclesia," or "civitas incendio penitus destructa," must often be taken to mean only that a bad fire happened in it. 
very narrow limits, and that the aggregate number must have been proportioned rather to the devotion and wealth of the founders than to the real wants of the citizens. In truth, the erection of a church or chapel in the 11 th and immediately succeeding centuries did not necessarily imply any living congregation at all. The object of the founder, as expressed in the current forms of dotation, was fully satisfied by the prayers of the ministrant "pro salubri statu dum vixerit, et pro salute animæ cum ex hac luce migraverit." There is, moreover, some ground for suspecting that the number of churches has been somewhat overrated. In the Appendix to the "History of Winchester," there is an imposing list of eighty churches and chapels, chiefly extracted from the episcopal registers of the 14th century, not including twelve collegiate and conventual churches. As we learn from the same authority that the glory of the city had then been waning for two hundred years, and that twenty, if not forty, churches had been destroyed in the reign of Stephen alone (Milner, vol. i. p. 162), Dr. Milner would compel us to conclude that Winchester, under Henry I., was the rival of Rome itself in excessive development of ecclesiastical architecture. ${ }^{9}$ Upon the whole I incline strongly to the opinion, that, although we cannot doubt the comparative importance of the city at this time, or the grandeur of those public structures, eastellated and conventual, of which the remains have survived almost to our own times, the enormous expansion of Winchester in the reign of the first Henry is a fable mainly founded on the apocryphal authority of Alderman Trussell and the imagination of Dr. Milner. ${ }^{1}$

In the latter part of the record there is a short statement of the revenue arising from the "consuetudines" or customs of the city. They consist of, -

The custom of burrells and chalons, already noticed.

The custom or toll paid at the city gates, with the profits of the fairs of St. Barnabas and St. Swithin.

The custom of pesage, or weighing of wool.

Payments made by "consuetudinarii," (customary tenants?) and in respect of petty customs.

Pleas and perquisites of the city courts.

Custom paid by persons upon entry or exit into or out of the city. This seems to be a toll traverse, distinct from the gate toll. One was, perhaps, a personal toll ; the other an octroi upon merchandise. ${ }^{2}$

The profits arising from permits or licences to merchants, and from escheats.

The above document suggests some further observations.

9 Some of the chapels (as those attached to the Castle) must have been private. The County Hall figures as the chapel of St. Stephen. Here, too, we must not confound a mediæval "capella" with a modern London proprietary or district chapel.

1 Some few years ago an opportunity was afforded to me by a friend of reading the MS. history of Winchester by Trussell. It is a loose, rambling work, of little, if any, value. The incompetency of the author to deal with matters of historical research is patent. Leslia, the Scotch his. torian, who wrote in the reign of James I., or Charles I., is cited as "Johannes Lesleus, Episcopus Rossensis, that wrote in the reign of Eugenius, third King of Scotland!" The date of Trussell's dedication is 1644 .

2 The gate custom and pesage are mentioned twice in the statement of revenues, but they are the same tolls or custom paid during two periods, viz. from Michaelmas to St. Giles, and from the Morrow of Holy Cross to Michaelmas, - leaving out the duration of St. Giles' fair, when all tolls ceased except those of the bishop. 
The conflict of jurisdiction between the crown and the lords of franchises, and between the lords of adjacent liberties, was a continual cause of complaint and litigation, especially when great cities were hemmed in by territorial franchises. The great Liberties of St. Romain, of St. Ouen, of Montivilliers, and Fecamp encompassed the city of Rouen, and penetrated far within its walls; hence the early history of that city is a tale of uninterrupted warfare between the municipal and ecclesiastical authorities, which did not always evaporate, like the Winchester disputes, in an inquest or a judgment in the king's courts. A quarrel between the canons of the cathedral and the trade-gilds of Rouen, in 1192, respecting a grievance closely similar to Bishop Raley's protection of the Winchester weavers, was not appeased without many anathemas and much bloodshed. (Cheruel, Hist. de Rouen, vol. i., p. 40, and seq. ; Id. p, 72, and vol. ii., pp. 114, 135, 137.) In the language of Sir Matthew Hale, such a franchise was a feather in the lord's cap, and a thorn in the king's side. The conflict of jurisdiction between the city of Winchester and the Hyde liberty continued for many years, as will be seen in the Hyde Register (Harl. MSS., No. 1761, fo. 35, 37), but seems to have been eventually settled in favour of the abbey. Indeed, if the Golden cartulary, preserved in the Cotton collection (Vesp. A. No. viii, fo. 37 ), be as authentic in matter as it is beautiful in caligraphy, the abbey had been favoured by Henry I. with a distinct grant of the "libertatem vici extra portam borealem ejusdem civitatis ;"- - a grant, however, in terms of obscure import and rather suspicious generality.

The transaction relating to Walter de Pavely, called in other records William de Pavilly, explains the grants in the Close rolls 17 Joh. 1215 (Rot. Lit. Claus, p. 219, 225), and justifies the conjecture of Mr. Hawkins that it was meant to be only a pecuniary gift of the rent or reversion to $W$. de P., and not to convey to him any privileges of the mint. The agreement of the mayor in 1247 , to give an increased rent of $60 \mathrm{~s}$. for the removal of the Drapery into the High Street, is also adverted to by Mr. Hawkins; but it should seem that the extra rent was actually paid to the crown by the city down to the date of the inquest, although the Pipe rolls, as cited by Madox (Firma Burgi. p. 19, n.) only debit the city with the amount. (See Notices of the Mint, \&c., at Winchester ; Proceedings of Arch. Inst., A.D. 1825 , pp. 37,38 .)

It is remarkable that the list of jurors supplies the names of two mayors, hitherto unnoticed, viz.-W. de Pavilly, mayor of Rouen, whose name does not occur in the list of $\mathrm{M}$. Chéruel ; and Nicholas Coppinger, mayor of Winchester, whose name is not to be found in the Winchester tables during the reign of Henry III.

The large house granted to King John's tailor, and used for the Linen Cloth Hall, was probably near the church of St. Mary De Linea Tela and opposite St. John's house. From the Testa de Nevill (p. 236, print. ed.), it appears that this house was in fact the Chepemanesela, or Chapman's-hall, which figures in the early Pipe rolls as rendering to the crown 20 marks of silver annually by the hand of the sheriff of Hants. (Pipe rolls, 31 Hen. I. ; 4 Hen. II. ; 1 Ric. I., \&c.) So that it continued to be a cloth hall after the rent and reversion had been granted away. It was probably the "Seld' ubi linei panni venduntur," noticed in the survey of 1148 (Lib. Wint. p. 544).

It would be curious to ascertain how long the serjeanty or service of rendering the fur pelisse or coat continued to be performed. The Close roll, 
9 John 1208, shows that one was duly delivered in that year (Rot. Claus. p. 101, printed ed.), and it is certain that William, or his son, continued to be the court tailor in the subsequent reign of Henry III. From the numerous orders given to him and favours bestowed on him during two reigns, he must have retired on a considerable fortune, and it would not be surprising if the blood of the tailor were now found to be flowing in patrician veins. The index to the printed Close rolls (title Scissor) refers to numerous entries relating to him.

The Mews, alluded to by the jury, are supposed to have been situate without the Westgate, and they are often noticed in the Close and Pipe rolls. But there were, perhaps, still earlier Mews at Winchester; for the "Meweneheia," i. e. Mews-hay, is specified among the crown demesnes in the reign of Henry I. (Liber Winton, p. 534). ${ }^{3} \quad$ From a record which I shall cite hereafter it would appear that the land had been purchased by Henry II., and not by John, and that the jury were therefore misinformed in this respect.

A large space in the document is occupied by the names of the langable tenants in each street, which are omitted in the above transcript. They are interesting only in respect of the opportunity they afford of comparing them with the earlier lists of tenants in the Liber Winton. The names of the tenants in the time of the Confessor are almost universally Saxon, and I see no ground for suspecting, with Bishop Lyttleton, that they were Normans disguised under Saxon names. Wherever the survey of Henry I. represents a change of tenancy, the new tenant has, in general, a Norman, or at least foreign, name; and the list is, upon the whole, of a mixed character. Again in the survey of 1148 , the same mixed character of names prevails, but, I think, with a greater tendency to surnames derived from trades or other sources which no longer indicate the country or descent of the bearer. The names in the above inquest of Edward I. show a great advance; and a large proportion of them, with a slight modification in the spelling, would pass for surnames of the present day. The names of the jury may be taken as fair specimens of them, and it appears to me that Messrs. Spicer, Poore, Stockbridge, Russel, Morant, Le Cras, Fulflood, Beaublet, Strut, Ockley, Capperidge, and Palmer, are as likely to be found in a jury box in the 19 th century as in the 13 th. It is observable that some, even of the earliest names recorded in any of the surveys, still survive in Winchester. Several in the Liber Winton might be mentioned. The Drews (Drogo), and some other familiar names among them were perhaps imports into the eity from abroad; but the good Saxon name of Seagrim is of indigenous growth, and will be recollected by those members of the Institute who experienced the polite attentions of the Under-sheriff of Hants in 1845.

To this notice, already too long, a few words must be added on the probable date of the above inquest. It has no date, heading, or indorsement, and we are left to conjecture the precise time and occasion of taking it. The commencement shows that it was taken in the reign of Edward I. and the tenor of its contents, as well as its place of deposit, seem to stamp it as the result of an inquiry on behalf of the crown. It is indeed apparent that the jurors are in the interest of the city; but as the citizens wero farmers under the crown, the interests of both were in fact nearly identical.

It is well known that a general inquiry into supposed usurpations on the crown took place in the beginning of the reign of Edward I., and the

3 It is possible that it should be read "Merewenehaia." 
recorded results form the series of records called the Hundred Rolls. The returns for Hampshire, as printed, are evidently defective, being confined to a small part of the county exclusive of Winchester. When the verdiets, taken on these inquisitions, alleged encroachments or threw doubt on the title of those who claimed under the crown, proceedings were in many instances adopted by the attorney-general to call the delinquents to account. These proceedings form the collection known and published as the Placita de Quo Warranto.

Now it is remarkable that in two of the cases noticed by the inquest, namely, those of the Abbot of Hyde and of Reginald Fitz Peter, proceedings were in fact commtenced by the crown in the eigthth year of Edward I.

In that year a writ of right was brought by the king against the Abbot of Hyde, to recover land usurped in the north suburb of the city, called Denemarche, and judgment was given for the crown. Again, a writ of Quo Warranto was filed against the same Abbot to question his title to the franchise of the Hundred of Micheldever ; but the defendant showed his title, and the prosecution was dropped. (Plac. de Quo Warranto, printed ed., pp. 766, 767 ; and Harl. MSS., No. 1761, fol. 31.)

In the same year a writ or action was prosecuted at the suit of the crown, alleging a disseisin by Reginald Fitz Peter of certain lands, "extra civitatem Wintoniæ." The defendant pleaded a grant by Henry III., in the forty-eighth year of his reign, and the grant (which is set forth) states the original purchase of the land by Henry II. ; its conversion into the mews ; its descent to Kings John and Henry, and the lawful conveyance of it by King Henry to the defendant. To this the king's attorney replied, that Henry's grant was made during the civil war, while he was in durance, and was therefore void. On proof that the war began on the 4th of April, $48 \mathrm{Hen}$. III. (1264), the grant, being of prior date, was adjudged to be good. (Plac. de Quo Warr., fo. 766.) It is clear that this was the land beyond the West Gate referred to in the Winchester inquest.

Hence we may reasonably infer that the inquest was taken before 8th Edward I., and that the proceedings in that year were instituted in consequence of it. We know that the other inquisitions extant in the Hundred Rolls were taken in Hampshire in the second and third years of the same reign; and I therefore venture to assign the same date to the document before us. Such, at least, is my present impression.

E. SMIRKE. 